\title{
抗生物質の抗菌力に及ぼす各種金属イオンの影響
}

\author{
第 3 報 傾斜平板法とブイョン稀粎法におりる検討 \\ 氏 家冬深 \\ 東京大学医学部細菌学教室 (主任 秋葉朝一郎教授)
}

[受付 : 8 月 6 日・ 1958 年]

細菌のメタボリズムに抬いて各種金属イオンの存在が 必須であるととは既に周知の事実である。また一方, 細 菌のメタボリズムを阻害するととによつて効力を発揮す るものに各種抗生物質がある。更にとれら両者の一部に 括いて特異的な結合や相互作用の存在するととも判つて いる。それ故, 抗生物質の抗菌力に及济す各種金属イオ ンの影響を知ることは細菌のメタボリズムの機作を知る ためにも非常に興味深いと思う。著者は, 先きに本研究 の第 1 報 ${ }^{1)}$ ，第 2 報 ${ }^{2)}$ において抗生物質 8 種 (Aureomycin, Terramycin, Tetracyclin, Culoromycetin, Dihydrostreptomycin, Penicillin, Ilotycin 及び Colimycin) と金属イオン 8 種 $\left(\mathrm{Al}^{3+}, \mathrm{Ca}^{2+}, \mathrm{Cu}^{2+}, \mathrm{Fe}^{2+}\right.$, $\mathrm{Fe}^{3+}, \mathrm{Mg}^{2+}, \mathrm{Mu}^{2+}$ 及び $\mathrm{Zn}^{+2}$ ) を用い, 先づ普通寒天 培地の承平拡散法 (Cup 法) により, 次に培地から 2 価 以上の陽イオンと金属不純物を除いた精製合成培地の稀 釈法により, 夫々との点を検討した。その結果, 或種の 抗生物質が或種の金属イオンと共存した場合その抗菌性 が著しく増堿する成績圭得, 作用機作について多少の考 察を加えた。今回は以上の知見字更に広く確認する目的 で抗生物質と金属イオンの両者共その種類を増加し, 所 謂傾斜平板法とブイヨン稀釈法とにより夫々同様の影響 を検討した。即ち, 抗生物質 9 種 (前記 8 種に Olean-. domycin 加引) と金属イオン20種(前記 8 種に, $\mathrm{Ag}^{1+}$, $\mathrm{Ba}^{2+}, \mathrm{Cd}^{2+}, \mathrm{Co}^{2+}, \mathrm{Cr}^{3+}, \mathrm{Hg}^{2+}, \mathrm{Li}^{1+}, \mathrm{Ni}^{2+}, \mathrm{Pb}^{2+}, \mathrm{Th}^{4+}$, $\mathrm{U}^{6+}$ 及び $\mathrm{Zr}^{4+}$ の 12 種を加う) を用い, 新た汇前回の 実験では認め得なかつた各種金属イオンの影響を多数例 につき観察することが出来た。また, Gram 陽性菌 (Staphylococcus aureus) 之同陰性菌 (Escherichia coli 他), 抗生物質に対する感受性菌之耐性菌の各者を用いて菌種 乃至菌株による成績の差異を比較した。その結果, 特に 著明な協力作用を示す金属イオンとして Tetracyclin
系物質に対する $\mathrm{Ba}, \mathrm{Cd}$ 及び $\mathrm{Cr}$, Dihydrostreptomycin やColimycin 伩対する Cd があり, 逆に特に著しい拮 抗作用在示すものとして Tetracyclin 系物質, Dihydrostreptomycin 及び Colimycin 等に対する $\mathrm{Mg}$, Colimycin に対するUが見出された。更に，とれら各系につ いて抗生物質と金属と両者の濃度比による抗菌性変化並 に作用機作を検討したが，作用機作に関する成績は次報 に述べる。

\section{実 驗}

\section{[第 1 部]}

\section{I. 実験材料}

菌株: (1) Gram 陽性菌 1 種 4 株 (Staphylococcus aureu $209 \mathrm{P}$ 株, 同97株の原株及び Penicillin-G $1000 \mathrm{u} / \mathrm{ml}$ 人工而性菌, Penicillinase 産生性の同村松株)。(2) Gram 陰性菌 2 種 5 株 (Escherichia coli B-19株, 同 Terramycin $100 \mathrm{mcg} / \mathrm{ml}$ 耐性菌, 同 Dihydrostreptomycin 1000 $\mathrm{mcg} / \mathrm{ml}$ 耐性菌, Vibrio cholerae イナバ原株, 同 Dihydrostreptomycin $1000 \mathrm{mcg} / \mathrm{ml}$ 耐性菌)

培地: 普通寒天培地 (肉エキス, ポリペプトン各 1.0 $\%$, 寒天 $2.0-3.0 \%$ )。普通ブイヨン培地 (肉エキス, ポリペプトン各 1.0\%)。培地の $\mathrm{pH}$ は共に 7.0 7.2。

抗生物質：各結晶性粉末 9 種。即与, Aureomycin$\mathrm{HCl}$ (武田提供, 以下略号 AM)。Terramycin-HCl (田 辺提供, 以下略号 TM)。Tetracyclin- $\mathrm{HCl}$ (田辺提供,

UJIIE Fuyumi : Studies on influences of metal ion on the action of several antibiotics. III. A comparative study on double gradient agar plates and ordinary dilution method. Department of Bacteriology, Faculty of Medicine, University of Tokyo - Jap. J. of Bact., 14(1), 32-41, 1959. 
以下略号 T C)。Dihydrostreptomycin- $\mathrm{H}_{2} \mathrm{SO}_{4}$ (明治, 以 下略号 S M)。Chloromycetin (三共, 以下略号 CM)。 Penicillin-GK（日本化薬提供, 以下略号 Pc)。 llotycin (塩野義提供, 以下略号 It)。Colimycin- $\mathrm{HCl}$ (八洲化 学, 以下略号 $\mathrm{Col}$ )。Oleandomycin (Pteizer 以下略号 OM)。

金属塩：各潐品又は之に準ず当もの 20 種。 $\mathrm{AgNO}_{3}$, $\mathrm{Al}\left(\mathrm{NO}_{3}\right)_{3} \cdot 9 \mathrm{H}_{2} \mathrm{O}, \mathrm{BaCl}_{2} \cdot 2 \mathrm{H}_{2} \mathrm{O}, \mathrm{CaCl}_{2} \cdot 2 \mathrm{H}_{2} \mathrm{O}, \mathrm{CdCl}_{2}$ - $2 \mathrm{H}_{2} \mathrm{O}_{2}, \mathrm{CO}\left(\mathrm{NO}_{3}\right)_{2} \cdot 6 \mathrm{H}_{2} \mathrm{O}, \mathrm{Cr}\left(\mathrm{NO}_{3}\right)_{3} \cdot 9 \mathrm{H}_{2} \mathrm{O}, \mathrm{CuSO}_{4}$ $5 \mathrm{H}_{2} \mathrm{O}, \mathrm{FeCl}_{2}, \mathrm{FeCl}_{3} \cdot 6 \mathrm{H}_{2} \mathrm{O}, \mathrm{HgCl}_{2}, \mathrm{LiCl}_{2}, \mathrm{MgSO}_{4} \cdot 7$ $\mathrm{H}_{2} \mathrm{O}, \mathrm{MnCl}_{2} \cdot 4 \mathrm{H}_{2} \mathrm{O}, \mathrm{NiSO}_{4} \cdot 7 \mathrm{H}_{2} \mathrm{O}, \mathrm{Pb}\left(\mathrm{NO}_{3}\right)_{2}$, Th $\left(\mathrm{NO}_{3}\right)_{4} \cdot 4 \mathrm{H}_{2} \mathrm{O}, \quad \mathrm{UO}_{2}\left(\mathrm{CH}_{3} \mathrm{COO}\right)_{2} \cdot 2 \mathrm{H}_{2} \mathrm{O}, \quad \mathrm{ZnSO}_{4} \cdot 7$ $\mathrm{H}_{2} \mathrm{O}, \mathrm{Zr}\left(\mathrm{NO}_{3}\right)_{4}$ 。

Chelating agent: Ethylene diamine tetraacetic acid $\mathrm{C}_{10} \mathrm{H}_{14} \mathrm{O}_{8} \mathrm{~N}_{2} \mathrm{Na}_{2} \cdot 2 \mathrm{H}_{2} \mathrm{O}$ (和光純葲, 以下略号EDTA) II. 実験方法

抗生物質の抗菌力に及济す金属イオンの影響を検討す るためには当然両者共に成るべく広範围の濃度について 試験する必要がある。又, その際特に注意すべき点は, 先ず第一に著しい影響の有無乃至強弱, 第二に濃度々影 響の各変化が平行するか, 第三汇両者が或る特定の濃度 比に执いて特殊の抗菌性変化京示す場合があるか等の諸 点である。もし, 以上の諸点に対する検討を液体培地の 稀釈法で行うとすれば莫大な組合圷の試験管系列を要す るだろう。しかしとの際, 所謂傾斜平板法を利用すれぼ 連続的な濃度変化仙抬いて両者の相互作用の有無老比較 的容易に検討出来る。兄社故, 本実験では先ず各抗生物 質と各金属塩との全組合永180種记つき夫々二重傾斜平 板 Double gradient agar plates (Weinberg, E. D., $1957^{33}$ ) を作成して前記諸点を検討した後, 普通ブイヨ ン稀釈法により各種影響に対する細部検討を行つた。

\section{A) 予備実験}

先ず抗生物質 9 種上金属塩20種の全部につき普通寒天 培地化招讨單独抗菌性の程度をしらべた。その結果, 傾斜平板孛作成した場合 (氷室内拡散18一-48時間),抗菌 性変化を観察するために最も適当な抗生物質濃度は大凡 次の如くであつた。Tetracyclin 系物質(AM, TM, TC) では約 $10^{-5}$ モル (以下Mと略す), Pc 治 $10^{-4} \mathrm{M}, \mathrm{S} \mathrm{M}$ $3.0 \times 10^{-6} \mathrm{M}, \mathrm{C} \mathrm{M}$ は $1.5 \times 10^{-5} \mathrm{M}$, It は Gram 陽性: 菌の場合 $2.5 \times 10^{-7} \mathrm{M}$, 同陰性菌の場合 $10^{-4} \mathrm{M}, \mathrm{OM}$ は $10^{-5} \mathrm{M}$ (同陽性菌の文使用), Col 注同陽性菌の堭合約 $10^{-4} \mathrm{M}$, 同陰性菌の場合約 $5.0 \times 10^{-6} \mathrm{M}$ である。た金 属塩注使用各菌怢飞対して全く抗菌性が認的られず且つ 沈溉形成を示さない最高濃度圭使用した。即与, 寒天抁
散法並びそブイヨン稀釈法に抬ける各金属塩添加濃度は 夫及大凡以下の如し。 $\mathrm{Ag}\left(10^{-5} \mathrm{M}, 2.5 \times 10^{-6} \mathrm{M}\right.$, ) $\mathrm{Al}(10$ $\left.{ }^{-3} \mathrm{M}, 10^{-4} \mathrm{M}\right), \mathrm{Ba}\left(10^{-3} \mathrm{M}, 10^{-3} \mathrm{M}\right), \mathrm{Ca}\left(10^{-3} \mathrm{M}, 10^{-3}\right.$ $\mathrm{M}), \operatorname{Cd}\left(5.0 \times 10^{-4} \mathrm{M}, 2.5 \times 10^{-4} \mathrm{M}\right), \mathrm{CO}\left(10^{-4} \mathrm{M}, 10^{-4}\right.$ $\mathrm{M}), \operatorname{Cr}\left(10^{-3} \mathrm{M}, 2.5 \times 10^{-4} \mathrm{M}\right), \mathrm{Cu}\left(10^{-3} \mathrm{M}, 10^{-3} \mathrm{M}\right)$, $\mathrm{Fe}^{2+}\left(10^{-3} \mathrm{M}, 10^{-4} \mathrm{M}\right), \mathrm{Fe}^{3+}\left(10^{-3} \mathrm{M}, 10^{-4} \mathrm{M}\right), \mathrm{Hg}\left(10^{-5}\right.$ $\left.\mathrm{M}, 10^{-6} \mathrm{M}\right), \mathrm{Li}\left(10^{-2} \mathrm{M}, 10^{-3} \mathrm{M}\right), \mathrm{Mg}\left(10^{-2} \mathrm{M}, 10^{-2} \mathrm{M}\right)$, $\mathrm{Mn}\left(10^{-3} \mathrm{M}, 10^{-3} \mathrm{M}\right), \mathrm{Ni}\left(10^{-3} \mathrm{M}, 10^{-3} \mathrm{M}\right), \mathrm{Pb}\left(10^{-3}\right.$ $\left.\mathrm{M}, 10^{-4} \mathrm{M}\right), \operatorname{Th}\left(10^{-3} \mathrm{M}, 10^{-4} \mathrm{M}\right), \mathrm{U}\left(10^{-3} \mathrm{M}, 10^{-4} \mathrm{M}\right)$, $\mathrm{Zn}\left(10^{-3} \mathrm{M}, 10^{-4} \mathrm{M}\right), \mathrm{Zr}\left(10^{-3} \mathrm{M}, 5.0 \times 10^{-4} \mathrm{M}\right)$ 。

B）寒天拡散法（二重傾斜平板法）

溶融後 50 - $60^{\circ} \mathrm{C}$ 亿保つた寒天培地一定量汇適当濃度の 各種金属塩 (邓恃抗生㸮質) の蒸溜水溶液を添加，良く 混和して所要濃度とした後, 底が一様に平らなシャーレ に流し迈及先ず斜位に凝固，冷却後との傾斜平板上に同 様汇各種挍生物質 ( 又は金属塩) 学混和した寒天培地等 量变重称，今度はシャーレを水平位儿凝固させる。Cの 様作成した二重傾斜平板注水室 $\left(5^{\circ} \mathrm{C}\right)$ 内に適当時間 （18一-48時間）静置し, 試験物質を充分拡散させた後, 各試験菌（ $37^{\circ} \mathrm{C} 18$ 時間ブイヨン培養）一白金耳量索平板 傾斜軸之平行して数条に塗抹, $37^{\circ} \mathrm{C}$ 培養 16 時間以後数日 閒にわたり適時試験菌の増殖程度学比輘観察した。抗生 物質と金属の各組合心飞ついては夫及平板 3 枚以上の平 均值をつつた。また, 対照系と比べて著明な変化が認め られた組合せでは添加金属塩濃度を変えて検討し，更に 金属塩と同時に E D T A (等モル量)を添加して金属イ オンの影響が回復するか否か学確かめた。な怙，上記の 様な二重傾斜平板上飞更灌い菌寒天層を重㸚る三重傾 斜平板法や，上下二層中どちらか一方を傾斜層他方を水 平層とする各種方法をも併用して試験した。以上の諸実 験に执いては各試験培地の $\mathrm{pH}$ はすべて対照培地の $\mathrm{pH}$ と可及的等しくある様汇修正しつつ実験を進めた。

C) ブイヨン稀釈法

濃縮ブイヨン $8 \mathrm{ml}$ に倍数稀釈した抗生物質と一定濃 度の金属塩の各蒸溜水溶液 $1 \mathrm{ml}$ 宛老添加混和, 夫及所 要濃度のふつうブイヨン溶液とした後, ブイヨン $37^{\circ} \mathrm{C} 18$ 時間培盖の試験菌 1 白金耳导接種, $37^{\circ} \mathrm{C} 18$ 時間培養以後 5 日間にわたり適時菌増殖の有無乃至程度を肉眼的に観 察した。各系培地の $\mathrm{pH}$ はすべて対照培地の $\mathrm{pH}$ と可 及的等しくある様汇修正した。

\section{III. 実験成績}
A. 寒天搪散法（傾斜平板法）飞招讨る成績（表(1) 参照)

1） Tetracyclin 系物質（AM, TM 及び TC）の抗 


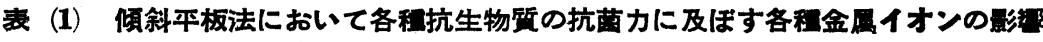

\begin{tabular}{|c|c|c|c|c|c|c|c|c|c|c|c|c|}
\hline \multirow{2}{*}{$\begin{array}{r}\text { Metal } \\
\text { ions }\end{array}$} & \multirow{2}{*}{$\begin{array}{l}\text { Antibiotics } \\
(\mathrm{M})\end{array}$} & \multirow{2}{*}{$\begin{array}{l}\mathrm{AM} \\
10^{-5}\end{array}$} & \multirow{2}{*}{$\begin{array}{l}\text { TM } \\
10^{-5}\end{array}$} & \multirow{2}{*}{$\begin{array}{l}\text { TC } \\
10^{-5}\end{array}$} & \multirow{2}{*}{$\begin{array}{c}\text { Pc } \\
10^{-4}\end{array}$} & \multirow{2}{*}{$\begin{array}{c}\mathrm{SM} \\
3.0 \times \\
10^{-6}\end{array} \mid$} & \multicolumn{2}{|c|}{ It } & \multirow{2}{*}{$\begin{array}{c}\mathrm{CM} \\
1.5 \times \\
10^{-5}\end{array}$} & \multirow{2}{*}{$\begin{array}{l}\mathrm{OM} \\
10^{-5}\end{array}$} & \multicolumn{2}{|c|}{ Col } \\
\hline & & & & & & & $10^{-4}$ & $\left|\begin{array}{c}2.5 \times \\
10^{-7}\end{array}\right|$ & & & $10^{-4}$ & $\begin{array}{r}5.0 \times \\
10^{-6}\end{array}$ \\
\hline $\mathrm{Ag}$ & $6.0 \times 10^{-6}$ & - & - & - & - & - & - & - & - & - & - & - \\
\hline $\mathrm{Al}$ & $7.0 \times 10^{-5}$ & $(\downarrow)$ & $(\downarrow)$ & $(\downarrow)$ & - & - & $(\downarrow)$ & - & - & - & - & - \\
\hline $\mathrm{Ba}$ & $5.0 \times 10^{-4}$ & $(\uparrow)$ & $(\uparrow)$ & $(\uparrow)$ & - & - & - & - & - & - & - & - \\
\hline $\mathrm{Ca}$ & $2.0 \times 10^{-4}$ & - & - & - & - & - & - & - & - & - & - & - \\
\hline $\mathrm{Cd}$ & $2.0 \times 10^{-4}$ & $\uparrow$ & $\uparrow$ & $\uparrow$ & - & - & $\uparrow$ & $\uparrow$ & $(\uparrow)$ & - & $\uparrow$ & $\uparrow$ \\
\hline Co & $10^{-5}$ & - & - & - & - & - & - & - & - & - & - & - \\
\hline $\mathrm{Cr}$ & $1.2 \times 10^{-4}$ & $(\uparrow)$ & $(\uparrow)$ & $(\uparrow)$ & - & - & - & - & - & - & $(\uparrow)$ & - \\
\hline $\mathrm{Cu}$ & $2.5 \times 10^{-4}$ & - & - & - & - & $(\uparrow)$ & $\downarrow$ & $(\downarrow)$ & - & - & - & - \\
\hline $\mathrm{Fe}^{+2}$ & $2.0 \times 10^{-4}$ & $\downarrow$ & $\downarrow$ & $\downarrow$ & - & - & $(\downarrow)$ & - & - & - & $(\downarrow)$ & - \\
\hline $\mathrm{Fe}^{+3}$ & " & $\downarrow$ & $\downarrow$ & $\downarrow$ & - & - & $(\downarrow)$ & - & - & - & - & - \\
\hline $\mathrm{Hg}$ & $7.0 \times 10^{-6}$ & - & - & - & - & - & - & - & - & - & - & - \\
\hline $\mathrm{Li}$ & $1.7 \times 10^{-3}$ & $(\downarrow)$ & $(\downarrow)$ & $(\downarrow)$ & - & - & - & - & - & - & - & - \\
\hline $\mathrm{Mg}$ & $10^{-3}$ & $\downarrow$ & $\downarrow$ & $\downarrow$ & - & $\downarrow$ & $\downarrow$ & - & - & - & - & - \\
\hline $\mathrm{Mn}$ & $2.5 \times 10^{-4}$ & - & - & - & - & - & - & - & - & - & - & - \\
\hline $\mathrm{Ni}$ & $2.0 \times 10^{-4}$ & - & - & - & $(\uparrow)$ & $(\downarrow)$ & - & - & - & - & - & - \\
\hline $\mathrm{Pb}$ & $6.0 \times 10^{-4}$ & - & - & - & - & - & - & - & - & - & - & - \\
\hline $\mathrm{Th}$ & $5.0 \times 10^{-4}$ & $\downarrow$ & $(\downarrow)$ & $\uparrow$ & $(\uparrow)$ & - & - & - & - & - & - & - \\
\hline $\mathbf{U}$ & " & - & - & - & - & - & - & - & - & - & - & - \\
\hline $\mathrm{Zn}$ & $2.5 \times 11$ & - & - & - & $\downarrow$ & - & - & - & - & - & $(\uparrow)$ & - \\
\hline $\mathrm{Zr}$ & $\prime \prime$ & - & - & - & - & $(\downarrow)$ & - & - & - & - & $(\downarrow)$ & - \\
\hline
\end{tabular}

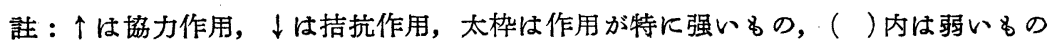

菌力に及浪す金属イオンの影響。

協力金属イオン: $\mathrm{Ba}, \mathrm{Cd}$ 及び $\mathrm{Cr} の 3$ 種, 特に $\mathrm{Cd}$ の協力作用が著しい。

拮抗金属イオン: $\mathrm{Al}, \mathrm{Fe}^{2+}, \mathrm{Fe}^{3+}, \mathrm{Li}, \mathrm{Mg}$ 及び $\mathrm{Th}$ の 6 種, 特に $\mathrm{Fe}^{2+}, \mathrm{Fe}^{3+}, \mathrm{Mg}$ 及び $\mathrm{Th}$ が顕著。

一般に Tetracyclin 系物質付対する金属イオンの作用 は Gram 陽性菌々同陰性菌との間で差異が少い。又,

AM, TM 及び TCの3者付する各金属イオンの影響 は大体一致平行するが，その程度には多少の強弱が認め られた。

2）Pcの抗菌力に及注す金属イオンの影響。
協力金属イオン : $\mathrm{Ni}$ 及び $\mathrm{Th}$. 但し不顥著。 拮抗金属イオン: $\mathrm{Zn}$ (E. coli の場合のみ)。

Pc の抗菌力に対する金属イオンの作用は一般に不䫓 著で且つ Gram 陰性菌の場合にのみ認められた。

3） S Mの抗菌力に及ぼす金属イオンの影響。

協力金属イオン: $\mathrm{Cu}$ (St. aureus 209Pの薬鼡感受性 菌の場合のみ)

拮抗金属イオン: $\mathrm{Mg}, \mathrm{Ni}$ 及び $\mathrm{Zr}(V$. cholerae の場 合のみ), $\mathrm{Mg}$ の拮抗作用は顥著。

4） It の抗菌力に及ぼす金属イオンの影㗽。

（a Gram 陽性菌の場合（It 濃度約 $2.5 \times 10^{-7} \mathrm{M}$ ) 


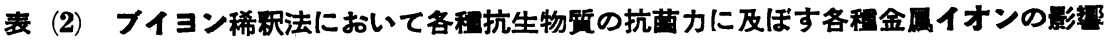

\begin{tabular}{|c|c|c|c|c|c|c|c|c|c|c|c|c|c|c|c|c|c|c|}
\hline \multirow{2}{*}{\multicolumn{2}{|c|}{ ions }} & \multicolumn{2}{|c|}{$\mathrm{AM}$} & \multicolumn{2}{|c|}{$\mathrm{TM}$} & \multicolumn{2}{|c|}{ TC } & \multicolumn{2}{|c|}{$\mathrm{Pc}$} & \multicolumn{2}{|c|}{ SM } & \multicolumn{2}{|c|}{ It } & \multicolumn{2}{|c|}{$\mathrm{CM}$} & \multirow{2}{*}{$\mid \begin{array}{c}O M \\
S \\
10^{-5} \\
1 \\
10^{-7}\end{array}$} & \multicolumn{2}{|c|}{ Col } \\
\hline & & $\begin{array}{c}\mathrm{E} \\
10^{-4} \\
1 \\
10^{-6}\end{array}$ & $\begin{array}{l}\mathrm{S} \\
\prime \prime\end{array}$ & $\begin{array}{l}\mathrm{E} \\
\prime \prime\end{array}$ & $\begin{array}{l}\text { S } \\
\prime \prime\end{array}$ & $\begin{array}{l}\text { E } \\
\prime \prime\end{array}$ & $\begin{array}{l}\mathrm{S} \\
\prime \prime\end{array}$ & $\begin{array}{c}\mathrm{E} \\
10^{-3} \\
\mid \\
10^{-4}\end{array}$ & $\mid \begin{array}{c}\mathrm{S} \\
10^{-6} \\
\vdots \\
10^{-7}\end{array}$ & $\begin{array}{c}\mathbf{E} \\
10^{-5} \\
\mid \\
10^{-6}\end{array}$ & $\begin{array}{c}\mathrm{S} \\
10^{-5} \\
\mid \\
10^{-7}\end{array}$ & $\begin{array}{c}\mathrm{E} \\
10^{-3} \\
\mid \\
10^{-6}\end{array}$ & $\begin{array}{c}\mathrm{S} \\
10^{-6} \\
\mid \\
10^{-8}\end{array}$ & $\begin{array}{c}\mathrm{E} \\
10^{-4} \\
\mid \\
10^{-6}\end{array}$ & $\begin{array}{c}\mathrm{S} \\
10^{-4} \\
\vdots \\
10^{-5}\end{array}$ & & $\begin{array}{c}\mathrm{E} \\
10^{-5} \\
\mid \\
10^{-7}\end{array}$ & $\begin{array}{c}\mathrm{S} \\
10^{-4} \\
1 \\
10^{-6} \\
\end{array}$ \\
\hline $\mathrm{Ag}$ & $1.5 \times 10^{-6}$ & - & - & - & - & - & - & - & - & - & - & - & 一 & 一 & 一 & -1 & $(\downarrow) \mid$ & - \\
\hline $\mathrm{Al}$ & $7.0 \times 11$ & - & - & 一 & - & 一 & 一 & - & - & - & - & - & 一 & 一 & 一 & 一 & -1 & $(\downarrow)$ \\
\hline $\mathrm{Ba}$ & $5.0 \times 10^{-4}$ & $(\uparrow)$ & $(\uparrow)$ & $\uparrow$ & $\uparrow$ & $\uparrow$ & $\uparrow$ & - & 一 & - & $(i)$ & - & - & - & - & - & - & - \\
\hline $\mathrm{Ca}$ & $3.0 \times 11$ & - & - & - & - & 一 & 一 & - & - & - & - & $|(\downarrow)|$ & - & - & - & -1 & $(\downarrow)$ & - \\
\hline Cd & $10^{-4}$ & $\uparrow$ & $(\uparrow)$ & $\uparrow$ & $(\uparrow)$ & $\uparrow$ & $(\uparrow)$ & - & - & $(\uparrow)$ & $\uparrow$ & $(\uparrow)$ & - & - & - & - & $\uparrow$ & - \\
\hline Co & $2.0 \times 10^{-5}$ & $(\downarrow)$ & -1 & $|(\downarrow)|$ & - & $(\downarrow)$ & - & - & - & - & - & - & - & $(\downarrow)$ & - & - & - & - \\
\hline $\mathrm{Cr}$ & $3.0 \times 11$ & $(\uparrow)$ & $\mid(\uparrow)$ & $(\uparrow$ & $(\uparrow)$ & $\uparrow$ & $(\uparrow)$ & $|(\uparrow)|$ & - & - & - & - & - & - & 一 & - & 一 & - \\
\hline $\mathrm{Cu}$ & $2.5 \times 10^{-4}$ & $(\downarrow)$ & - & $|(\downarrow)|$ & - & $(\downarrow)$ & - & - & - & $(\uparrow)$ & $(\uparrow)$ & $|(\downarrow)|$ & - & $(\downarrow)$ & - & - & $|(\downarrow)|$ & - \\
\hline $\mathrm{Fe}^{2+}$ & $2.0 \times 10^{-5}$ & $(\downarrow) \mid$ & $|(\downarrow)|$ & $|(\downarrow)|$ & $|(\downarrow)|$ & $|(\downarrow)|$ & $|(\downarrow)|$ & - & - & - & - & $|(\downarrow)|$ & 一 & - & 一 & 一 & - & $(\downarrow)$ \\
\hline $\mathrm{Fe}^{3+}$ & $\prime \prime$ & - & - & - & - & - & - & - & - & - & - & $(\downarrow) \mid$ & - & - & - & - & - & $(\downarrow)$ \\
\hline $\mathrm{Hg}$ & $7.0 \times 10^{-7}$ & - & - & - & - & - & - & - & - & - & - & - & - & - & - & - & - & - \\
\hline $\mathrm{Li}$ & $2.0 \times 10^{-4}$ & - & - & - & - & - & - & - & - & - & - & - & - & - & - & - & $(\downarrow)$ & - \\
\hline $\mathrm{Mg}$ & $10^{-3}$ & $\downarrow$ & $(\downarrow)$ & $|(\downarrow)|$ & $(\downarrow)$ & $|(\downarrow)|$ & $|(\downarrow)|$ & - & - & $(\downarrow)$ & $\downarrow$ & $(\downarrow)$ & - & - & - & - & $(\downarrow)$ & $\downarrow$ \\
\hline $\mathrm{Mn}$ & $2.5 \times 10^{-4}$ & - & - & - & - & - & - & - & - & - & - & $\mid(\uparrow)$ & 一 & - & - & $(\downarrow)$ & - & - \\
\hline $\mathrm{Ni}$ & $2.0 \times 11$ & $(\downarrow)$ & - & $(\downarrow) \mid$ & - & $(\downarrow)$ & $|(\downarrow)|$ & - & - & - & $(\uparrow)$ & $\mid(\uparrow)$ & - & - & - & $(\downarrow)$ & - & $(\downarrow)$ \\
\hline $\mathrm{Pb}$ & $6.0 \times 10^{-5}$ & - & $(\uparrow)$ & - & $(\uparrow)$ & - & $(\uparrow)$ & $1-$ & $|(\downarrow)|$ & - & - & $(\uparrow)$ & - & - & - & - & - & $(\downarrow)$ \\
\hline Th & $4.0 \times 11$ & - & - & - & - & - & - & - & - & - & - & $(\uparrow)$ & - & - & - & - & - & - \\
\hline $\mathbf{U}$ & $5.0 \times 11$ & - & - & - & - & - & - & - & - & - & - & $(\uparrow)$ & - & - & - & -1 & $(\downarrow)$ & $\downarrow$ \\
\hline $\mathrm{Zn}$ & $2.5 \times 11$ & - & - & - & - & - & - & $(\downarrow)$ & $|(\downarrow)|$ & $|(\downarrow)|$ & - & $\mid(\uparrow)$ & - & - & - & $(\uparrow)$ & $|(\downarrow)|$ & - \\
\hline $\mathrm{Zr}$ & $10^{-4}$ & - & - & - & - & - & - & $(\uparrow)$ & - & - & - & - & - & - & - & - & - & $(\downarrow)$ \\
\hline
\end{tabular}

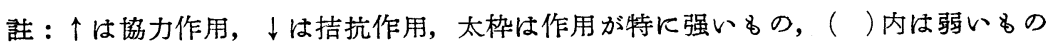

協力金属イオン: Cd 作用が顥著

拮抗金属イオン: $\mathrm{Cu}$

(b) Gram 陰性菌の場合 (It 濃度約 $10^{-4} \mathrm{M}$ )

協力金属イオン: Cd の作用が顕著。

拮抗金属イオン: $\mathrm{Al}, \mathrm{Cu}, \mathrm{Fe}^{2+}, \mathrm{Fe}^{3+}$ 及び $\mathrm{Mg}$, 特に

$\mathrm{Cu}$ と $\mathrm{Mg}$ の作用が顕著。Gram 陽性菌の場合は $\mathrm{Mg}$ 其他の拮抗作用が認められなかつたが之は It 濃度が低 いためと考えられる。

5） CMの抗菌力に及法す金属イオンの影響

協力金属イオン : Cd (E. coli の薬剤感受性菌の場合
の夕)

拮抗金属イオン:なし。

6） OM の抗菌力に及洔す金属イオンの影響。

Gram 陰性菌は一般に OM 感受性が低いため Gram 陽性菌のみを用いた。

協力金属イオン:なし

拮抗金属イオン:なし

7） Col の抗菌力に及ぼす金属イオンの影響

(a) Gram 陽性菌の場合 (Col 濃度約 $\left.10^{-4} \mathrm{M}\right)$

協力金属イオン: $\mathrm{Cd}, \mathrm{Cr}$ 及び $\mathrm{Zn}$, 特に $\mathrm{Cd}$ の作用 
が顕著。

拮抗金属イオン: $\mathrm{Fe}^{2+}$ 及び $\mathrm{Zr}$ (Pc 人工而性菌の場合 の文)

(1) Gram 陰性菌の場合 (Col 濃度約 $5.0 \times 10^{-6} \mathrm{M}$ )

協力金属イオン: Cd の作用が著しい。

拮抗金属イオン:なし

Gram 陰性菌で金属イオンの影響が 少数なのは Col 濃度加低いためと考えられる。

以上，各抗生物質の抗菌力に及汸す各金属イオンの影 響（協力又は拮抗）はすべて両者の連続的濃度变化につ いて観察された。そして其の際, 協力作用水上怙损作

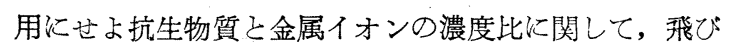
離れた抗菌性变化を示す様な特別な組合せは 1 例も認め られなかつた。即ち, 各系の菌堌殖阻止帯の増減はすべ て対照系のそれと連続的に認められ, それ故各金属イオ ンの影響は原則として濃度の増減と平行すると推定され た。

B）ブイヨン稀釈法に括ける成績（表 (2) 参照) 傾斜平板法の成績から, 各抗生物質一金属系に注著し い抗菌性変化を示す特殊な濃度比領域が存在せず, 従つ て各金属イオンの影響は濃度が高い程著しいと考えられ た。そとで, ブイヨン稀釈法に招讨る各金属の添加濃度 は一般に夫々単独抗菌性子沈溉形成も認められない範囲 で最高の濃度安使用した。また, Gram 陽性菌々同陰性 菌とで金属イオンの影響が異るととが判つたので, 前者 の代表として St. aureus 209 P 株, 後者の代表として E. coli B-19株を用いた。

1) Tetracyclin 系物質 (AM, TM 及ర): TC) の抗菌 力に及に゙す金属イオンの影響

(a) St: aureus 使用の場合 (各物質共濃度 $10^{-4}-10^{-6} \mathrm{M}$ ) 協力金属イオン $: \mathrm{Ba}\left(37^{\circ} \mathrm{C} 18\right.$ 時間培養時の最小菌増殖 阻止濃度による協力程度は T M と T Cでは約 10 倍, $\mathrm{AM}$ では約 2 倍), $\mathrm{Cd}$ (いずれも約 2 倍), $\mathrm{Cr}$ (約 2 倍), $\mathrm{Pb}$ (約 2 倍)

拮抗金属イオン: $\mathrm{Fe}^{2+}$ (上記同様の条件で拮抗程度は 約 2 倍), $\mathrm{Mg}$ (約 2 倍), $\mathrm{Ni}$ ( $\mathrm{TC}$ の場合の及, 約 2 倍)。

(b) E. coli 使用の場合 (同上)

協力金属イオン: $\mathrm{Ba}$ (TM と TC では約 8 倍, $\mathrm{AM}$ では約 2 倍), $\mathrm{Cd}$ ( $\mathrm{AM}$ と TMでは約10倍, T Cでは約

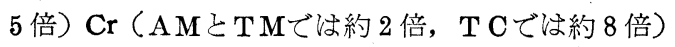

拮抗金属イオン: Co (いずれも約 2 倍), $\mathrm{Cu}$ (約 2 倍), $\mathrm{Fe}^{2+}$ (約 2 倍), $\mathrm{Mg}$ ( $\mathrm{AM}$ では約 4 倍, TM では約 2 倍), $\mathrm{Ni}$ (約 2 倍)

以上の如く, Tetracyclin 系物質に対する各種金属イ

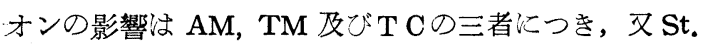

aureus と E. coli 両者につき大体汇捛いて同一傾向在示 すが, 作用程度の強弱関しては夫从可成り著しい差異 が認められた。

2） Pcの抗菌力に及济す金属イオンの影響

(a) S. aureus 使用の場合 ( $\mathrm{Pc}$ 濃度 $\left.10^{-6}-10^{-7} \mathrm{M}\right)$

協力金属イオン:なし

拮拉金属イオン: $\mathrm{Pb}$ (約 2 倍), $\mathrm{Zn}$ (約 2 倍)

(b) E. coli 使用の場合 ( $\mathrm{Pc}$ 濃度10 $0^{-3}-10^{-4} \mathrm{M}$ )

協力金属イオン: $\mathrm{Cr}$ (約 2 倍), $\mathrm{Zr}$ (約 2 倍)

拮抗金属イオン: $\mathrm{Zn}$ (約 2 倍)

以上の如く Pc の抗菌力江影響する金属イオンは少数 で且つ作用が弱い。

3） S M の抗菌力纫及汸す金属イオンの影響

(a) St. aureus 使用の場合 ( S M 濃度 $10^{-5}-10^{-7} \mathrm{M}$ )

協力金属イオン: $\mathrm{Ba}$ (約 2 倍), $\mathrm{Cd}$ (約 4 倍) $\mathrm{Cu}$ (約 2 倍), $\mathrm{Ni}$ (約 2 倍)

拮㧍金属イオン: $\mathrm{Mg}$ (約 5 倍)

(b) E. coli 使用の場合 ( $\mathrm{S} \mathrm{M}$ 濃度 $10^{-5}-10^{6} \mathrm{M}$ )

協力金属イオン: $\mathrm{Cd}$ (約 2 倍), $\mathrm{Cu}$ (約 2 倍)

拮抗金属イオン: $\mathrm{Mg}$ (約 2 倍), $\mathrm{Zu}$ (約 2 倍)

以上の如! S Mの抗菌性江対しては $\mathrm{Cd}$ の協力作用子 $\mathrm{Mg}$ の拮抗作用も共に St. aureus 使用の場合の方が著 明であつた。

4）It の抗菌力に及洼す金属イオンの影響

(a) St. aureus 使用の場合 (It 濃度 $\dot{5} .0 \times 10^{-7}-5.0 \times$ $10^{-8} \mathrm{M}$ )

協力金属イオン:なし

拮抗金属イオン:なし

(b) E. coli 使用の場合 (It 濃度 $5.0 \times 10^{-4} \mathrm{M}-5.0 \times$ $10^{-6} \mathrm{M}$ )

協力金属イオン: $\mathrm{Cd}, \mathrm{Mn}, \mathrm{Ni}, \mathrm{Pb}, \mathrm{Th}, \mathrm{U}, \mathrm{Zn}$ (以上 すべて約 2 倍)

拮抗金属イオン: $\mathrm{Ca}, \mathrm{Cu}, \mathrm{Fe}^{2+}, \mathrm{Fe}^{3+}, \mathrm{Mg}$ (以上文 べて約 2 倍)

St. aureus 使用の場合に金属イオンの影響が認められ ないのは It 濃度が低いためと考えられる。

5）CMの抗菌力に及济す金属イオンの影響

(a) St. aureus 使用の場合 ( C M濃度 $\left.5.0 \times 10^{-5}-10^{-5} \mathrm{M}\right)$

協力金属イオン:なし

拮抗金属イオン:なし

(b) E. coli 使用の場合 ( C M濃度 $2.5 \times 10^{-5}-10^{-6} \mathrm{M}$ )

協力金属イオン: 机

拈抗金属イオン: $\mathrm{Co}, \mathrm{Cu}$ (両者共約 2 倍)

以上の如く CMの抗菌性は一般に金属イオンの作用を 
受け難いものと考えられる。

6） OMの抗菌力に及洔す金属イオンの影響

(St. aureus の文使用)

協力金属イオン:なし

拮掟金属イオン: $\mathrm{Mn}, \mathrm{Ni}$ (両者共約 2 倍)

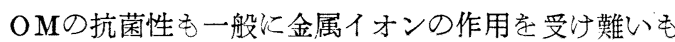

のと考えられる。

7） Col の抗菌力に及济す金属イオンの影響

(a) St. aureus 使用の場合 (Col 濃度10-4 $5.0 \times 10^{-6}$ M)

協力金属イオン:なし

拮挍金属イオン: $\mathrm{Al}, \mathrm{Fe}^{2+}, \mathrm{Fe}^{3+}$ (以上すべて約 2 倍), $\mathrm{Mg}$ (約 8 倍), $\mathrm{Ni}, \mathrm{Pb}$ (両者共飞約 2 倍), U(約 8 倍), $\mathrm{Zr}$ (約 2 倍)

(b) E. coli 使用の場合 $\left(\mathrm{Col}\right.$ 濃度 $\left.10^{-5}-10^{-7} \mathrm{M}\right)$

協力金属イオン: $\mathrm{Cd}$ (約 40 倍), $\mathrm{Zn}$ (約 2 倍)

拮抗金属イオン: $\mathrm{Ag}, \mathrm{Ca}, \mathrm{Cu}, \mathrm{Li}, \mathrm{Mg}, \mathrm{U}$ (以上す心゙ て約 2 倍)

以上の如く Col の抗菌性に対する金属イオンの影響 恃 St. aureus 使用の場合と E. coli 使用の場合とで著 しい差異が認められた。

\section{小 括}

1）傾斜平板法では, 抗生物質 9 種亡金属イオン 20 種 之の全組合世 180 系中加, 協力作用系17種 拈抗作用 系 29 種, 総計 46 種の存在を認め\%。特汇湿著なむのは Tetracyclin 系物質 (AM, TM 及び TC) 飞対する Cd の協力, $\mathrm{Fe}^{2+}$ と $\mathrm{Mg}$ の拮抗, It 位する $\mathrm{Cd}$ の協力と $\mathrm{Mg}$ の拮抗， $\mathrm{Col}$ 飞対する $\mathrm{Cd}$ の協力等であつた。

2）ブイヨン稀釈法では 同様の全組合达 180 系中衣 ら, 協力作用系 27 種, 拮抗作用系 40 種, 総計 67 種の存在 を認めた。特に著しいものは Tetracyclin 紊物質に対す $\mathrm{Ba}, \mathrm{Cd}, \mathrm{Cr}$ の各協力, $\mathrm{Mg}$ の拮抗, $\mathrm{S} \mathrm{M}$ 位対する $\mathrm{Cd}$ の協力 $\mathrm{Mg}$ の拮抗, $\mathrm{Col}$ 汶対する $\mathrm{Cd}$ の協力, $\mathrm{Mg}$ 及 でしの拮抗等であつた。

3）傾斜平板法とブイヨン稀釈法の両成績を比較する 之両者間注は多くの差異が認められた。即与, 両者の協 力作用系合計 44 種中, 両者共通のものは12種に過ざずぎ ちらか一方に揖いての及認められたものが22種あつた。

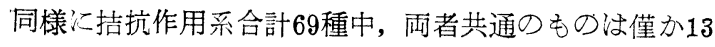
種であり非共通のものが42種であつた。また，拡散法で 認氻られた稀釈法では認められなかつたもの恊力作用 系 7 種, 拮抗作用系16種であり, 逆江稀釈法で認められ 拡散法では認められなかつたものは協力作用系 16 種, 拮
抗作用系 29 種の多き数充た。之れ故, 㧒生物質の抗菌 力に及汸す金属イオンの影響は拡散法よりも稀釈法に拧 いて敏感に出現すると考元られ认。

4）抗生物質之金属イオンの協力乃至拮挍作用は, 各 種使用菌株 (St. aureus, E. coli, V. cholerae, 各種抗生 物質感受性又性耐性菌等）位対乙共通仁認的られる場合 己然らざる場合とがあつ六。また一方数種の莰生物質に

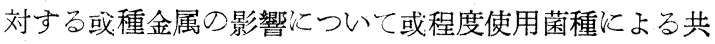
通性が認められる場合が市つ灾。

\section{〔第 2 部】}

第 1 部の実験成績から特に顕著な抗菌性変化が認めら れた抗生物質一金属系 9 種交選び，抗生物質の抗菌力変 化と添加金属イオン濃度との相互関係について細部検討 を試文た。

\section{I. 実験材料}

最も著しい協力作用系 5 種 (1) AM-Cd 系, (2) TM$\mathrm{Ba}$ 系, (3) TC-Cr 系, (4) SM-Cd 系, (5) Col-Cd 系) と最も著しい拮㧍作用系 4 種 (6) AM-Mg 系, (7) SM$\mathrm{Mg}$ 系, (8) Col-Mg 系, (9) Col-U 系)である。また, 実験菌株は各系につき夫々最も敏感反応した菌種を使 用した。従つて, (1), (3), (5), (6)の 4 系では, E. coli $\mathrm{B}^{-}$ 19 株, (2), (4), (6), (7), (8)の5系に対しては St. aureus $209 \mathrm{P}$ 株の各薬剤感受性菌を選んだ。

\section{II. 実験方法}

第1部のブイヨン稀釈法と同じ。但し各金属はふつう ブイヨン ( $\mathrm{pH}$ 6.8-7.2) 中で肉眼的沈溉老生じない最 高濃度附近方顺次倍数稀釈して添加し认。成績判定は $37^{\circ} \mathrm{C} 24$ 時間培養後, 菌增殖による培地の混濁安肉眼的 に比較観察して行った。

III. 実験成績

A. 協力作用を示卞挍主物質一金属系

(1) AM-Cd 系 (E. coli B-19 株使用): 協用作用に扔 けるAM Cd の呩度比の関係法表( 3 )の如くである。

(2) TM-Ba 系 (St. aureus 209 卫株使用): 協力作用 に打汀るTMと Ba の濃度比の関係は表 (4) の如くて ある。

(3) TC-Cr 系 (E. coli B -19 株使用): 協力作用火招 ける TC と Cr の濃度比の関係法表 (5)の如くである。

(4) SM-Cd 系 (St. aureus 20n'p株使用): 協力作用任 打汀 SM と Cd の濃度比の関係结表 (6) の如くて ある。

(5) Col-Cd 系 (E. coli B-19株使用): 協力作用におけ る Col と Cd の濃度比の関係は表 (7)の如くである。 B. 拮挍作用を示守㧧生物質一金属系 
表（3）協力作用における $\mathbf{A M} と \mathbf{C d}^{2+}$. の瀿度比の関係

\begin{tabular}{|c|c|c|c|c|c|c|c|c|}
\hline $\begin{array}{l}\mathrm{Cd}^{2+} \\
\quad(\mathrm{M}) \\
\end{array}$ & $\begin{array}{l}\stackrel{0}{\dot{0}} \\
\dot{\vec{x}} \\
0 \\
\dot{10}\end{array}$ & $\begin{array}{l}z \\
x \\
x \\
i \\
\text { id }\end{array}$ & $\begin{array}{l}\bar{x} \\
\dot{x} \\
0 \\
\dot{-}\end{array}$ & $\begin{array}{l}\dot{0} \\
\dot{\vec{x}} \\
0 \\
\dot{0}\end{array}$ & $\begin{array}{l}= \\
x \\
i \\
i \\
\text { o. }\end{array}$ & $\begin{array}{l}= \\
x \\
0 \\
\text { - }\end{array}$ & $\begin{array}{l}\hat{\dot{c}} \\
\vec{x} \\
\dot{0} \\
\dot{\rho}\end{array}$ & 0 \\
\hline $5.0 \times 10^{-4}$ & $\cdots$ & $\cdots$ & $\cdots($ & & 澱 & $\cdots$ & $\cdots$ & $\cdots \cdot$ \\
\hline $2.0 \times 11$ & - & - & - & - & - & - & + & H \\
\hline $1.0 \times 11$ & - & - & - & - & - & H & $\mathrm{HH}$ & $\mathrm{HH}$ \\
\hline $5.0 \times 10^{-5}$ & - & - & - & - & H & $\mathrm{H}$ & $\mathrm{tH}$ & $\mathrm{HH}$ \\
\hline $2.5 \times 11$ & - & - & - & - & $H$ & $\mathrm{HH}$ & $\mathrm{HH}$ & $\mathrm{HH}$ \\
\hline $1.0 \times 11$ & - & - & + & $H$ & $\mathrm{HH}$ & H & $\mathrm{HH}$ & $\mathrm{HH}$ \\
\hline $5.0 \times 10^{-6}$ & - & - & + & H & $\mathrm{HH}$ & $\mathrm{HH}$ & $\mathrm{HH}$ & $\mathrm{HH}$ \\
\hline $2.5 \times 11$ & - & $H$ & $H$ & Ht & HH & $\mathrm{HH}$ & $\mathrm{Ht}$ & $\mathrm{HW}$ \\
\hline 0 & - & H & H & $\mathrm{HH}$ & $\mathrm{HH}$ & $\mathrm{H}$ & $\mathrm{Ht}$ & H \\
\hline
\end{tabular}

（4）協力作用における $\mathbf{T M} と \mathbf{B a}^{2+}$ の漕度比の関係

\begin{tabular}{|c|c|c|c|c|c|c|c|c|c|}
\hline $\begin{array}{r}\mathrm{Ba}^{2+} \\
(\mathrm{M})\end{array}$ & $\begin{array}{l}\bar{j} \\
\dot{a} \\
x \\
0 \\
-i\end{array}$ & $\begin{array}{l}\stackrel{0}{0} \\
\frac{1}{x} \\
0 \\
\text { is }\end{array}$ & $\begin{array}{l}\bar{x} \\
\dot{x} \\
\stackrel{6}{0} \\
\text { is }\end{array}$ & $\begin{array}{l}\Sigma \\
x \\
0 \\
\dot{r}\end{array}$ & $\begin{array}{l}\stackrel{0}{0} \\
\vec{x} \\
0 \\
10\end{array}$ & $\begin{array}{l}= \\
x \\
0 \\
o \\
o\end{array}$ & $\begin{array}{l}= \\
x \\
0 \\
0 \\
-i\end{array}$ & $\begin{array}{l}\tilde{i} \\
\dot{x} \\
0 \\
\dot{0}\end{array}$ & : \\
\hline $5.0 \times 10^{-3}$ & H & H & H & $H$ & $H$ & $H$ & H & $H$ & H \\
\hline $2.5 \times 11$ & - & - & - & H & $H$ & $H$ & $H$ & $H$ & $H$ \\
\hline $1.0 \times 11$ & - & - & - & - & - & - & + & H & H \\
\hline $5.0 \times 10^{-4}$ & - & - & - & - & - & - & H & $H$ & H \\
\hline $2.5 \times 11$ & - & - & - & - & - & + & H & $H$ & H \\
\hline $1.0 \times 11$ & - & - & - & - & - & + & H & H & H \\
\hline $5.0 \times 10^{-5}$ & - & - & - & + & + & $H$ & H & $H$ & $H$ \\
\hline $2.5 \times 11$ & - & - & - & + & H & H & H & H & H \\
\hline $1.0 \times 11$ & - & - & - & H & H & H & H & H & H \\
\hline $5.0 \times 10^{-6}$ & - & - & + & H & H & $H$ & H & H & H \\
\hline 0 & - & - & + & $H$ & H & $H$ & $H$ & $H$ & $H$ \\
\hline
\end{tabular}

(6) AM-Mg 系 (E. coli B-19株使用): 拮挍作用に扮 ける $\mathrm{AM} と \mathrm{Mg}$ の濃度,比の関係は表( 8 )の如くである。

(7) SM-Mg 系 (St. aureus 209 卫株使用): 拮抗作用 に打ける S M と Mg の濃度此の関係は表（9）の如くで ある。

(8) Col-Mg 系 (St. aureus $209 \mathrm{P}$ 株使用): 拮招作用认 扮ける Col と $\mathrm{Mg}$ の濃度,比の関係は表(10)の如くであ る。

(9) Col-U 系 (St. aureus 209 卫株使用): 拮抗作用に おける Col とUの濃度比の関係牥表（11）の如くであ る。

以上の諸成績から，(1)一(9の各系について協力又は拮 抗作用を示す各抗生物質と各金属イオンとの最小濃度
表（5）協力作用における $\mathbf{T C} と \mathbf{C r}^{3+}$ の蕜度比の関係

\begin{tabular}{|c|c|c|c|c|c|c|c|c|}
\hline $\mathrm{Cr}^{3+}(\mathrm{M})$ & $\begin{array}{l}\stackrel{0}{0} \\
\dot{y} \\
\dot{x} \\
\dot{0}\end{array}$ & 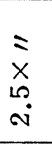 & $\begin{array}{l}\bar{x} \\
\dot{x} \\
0 \\
-\end{array}$ & $\begin{array}{l}\dot{b} \\
\stackrel{\vec{x}}{x} \\
0 \\
\dot{0}\end{array}$ & $\begin{array}{l}= \\
x \\
x \\
\text { of } \\
\text { of }\end{array}$ & $\begin{array}{l}= \\
x \\
0 \\
\text { - } \\
-\end{array}$ & $\begin{array}{l}\hat{0} \\
\dot{y} \\
\dot{x} \\
0 \\
\dot{0}\end{array}$ & 0 \\
\hline $2.5 \times 10^{-4}$ & $\cdots$ & $\cdots$ & $\cdots$ (in & & 满 & . & . & $\cdots$ \\
\hline $1.0 \times 11$ & - & - & - & - & + & H & Ht & $\mathrm{Ht}$ \\
\hline $5.0 \times 10^{-5}$ & - & - & - & - & + & H & $\mathrm{HH}$ & H \\
\hline $2.5 \times 11$ & - & - & - & + & H & $H$ & H & H \\
\hline $1.0 \times 11$ & - & - & + & H & H & $\mathrm{tH}$ & $\mathrm{HH}$ & Ht \\
\hline $5.0 \times 10^{-6}$ & - & - & + & $H$ & H & $\mathrm{HH}$ & H & H \\
\hline $2.5 \times 11$ & - & + & $H$ & $H$ & $\mathrm{HH}$ & Ht & H & $\mathrm{HH}$ \\
\hline $1.0 \times 11$ & - & $H$ & $\mathrm{Ht}$ & $\mathrm{HH}$ & $\mathrm{HH}$ & tH & $\mathrm{Ht}$ & $\mathrm{HH}$ \\
\hline 0 & - & $H$ & $\mathrm{H}$ & $\mathrm{HH}$ & $\mathrm{HH}$ & $\mathrm{HH}$ & $\mathrm{HH}$ & H \\
\hline
\end{tabular}

表（6） 協力作用における $\mathbf{S M ~ と ~} \mathbf{C d}^{2+}$ の濃度比の関係

\begin{tabular}{|c|c|c|c|c|c|c|c|c|}
\hline $\begin{array}{l}\mathrm{Cd}^{2+} \\
(\mathrm{M}) \\
\end{array}$ & $\begin{array}{l}\dot{0} \\
\stackrel{0}{x} \\
\dot{x} \\
0 \\
-\end{array}$ & $\begin{array}{l}\hat{\dot{0}} \\
\dot{x} \\
0 \\
\dot{0}\end{array}$ & 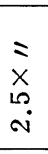 & $\begin{array}{l}\bar{x} \\
x \\
0 \\
\dot{r}\end{array}$ & $\begin{array}{l}\dot{0} \\
\frac{1}{x} \\
0 \\
\text { is }\end{array}$ & $\begin{array}{l}= \\
x \\
\text { L } \\
\text { of } \\
\text { vi }\end{array}$ & $\begin{array}{l}= \\
\dot{x} \\
0 \\
-1\end{array}$ & 0 \\
\hline $5.0 \times 10^{-4}$ & $\cdots \cdots$ & $\cdots$ & $\cdots$ & & 澱 & $\cdots$ & $\cdots$ & $\cdots$ \\
\hline $2.5 \times 11$ & - & - & - & + & + & + & H & $H$ \\
\hline $1.0 \times 11$ & - & - & - & + & + & $H$ & H & $H$ \\
\hline $5.0 \times 10^{-5}$ & - & - & - & + & H & $H$ & $H$ & $H$ \\
\hline $2.5 \times 11$ & - & - & - & $H$ & H & $H$ & $H$ & $H$ \\
\hline $1.0 \times 11$ & - & - & + & $H$ & $H$ & $H$ & H & $H$ \\
\hline $5.0 \times 10^{-6}$ & - & - & $H$ & $H$ & H & $H$ & H & $H$ \\
\hline $2.5 \times 11$ & - & - & H & $H$ & H & $H$ & H & $H$ \\
\hline $1.0 \times 11$ & - & - & H & $H$ & H & $H$ & H & $H$ \\
\hline 0 & - & + & H & $H$ & H & $H$ & H & $H$ \\
\hline
\end{tabular}

（M）比をしらべると大体次の䇐な関係が認められた。 即与, 協力作用系で
A）協力作用系
濃度比
(1) $\mathrm{AM}\left(2.5 \times 10^{-5} \mathrm{M}\right): \mathrm{Cd}^{2+}\left(5.0 \times 10^{-6} \mathrm{M}\right) \quad 5$
(2) $\mathrm{TM}\left(2.5 \times 10^{-5} \mathrm{M}\right): \mathrm{Ba}^{2+}\left(1.0 \times 10^{-6} \mathrm{M}\right) \quad 2.5$
(3) $\mathrm{T} \mathrm{C}\left(2.5 \times 10^{-6} \mathrm{M}\right): \mathrm{Cr}^{3+}\left(2.5 \times 10^{-6} \mathrm{M}\right) \quad 1$
(4) $\mathrm{S} \mathrm{M}\left(5.0 \times 10^{-7} \mathrm{M}\right): \mathrm{Cd}^{2+}\left(1.0 \times 10^{-6} \mathrm{M}\right) \quad 0.5$
(5) $\mathrm{Col}\left(5.0 \times 10^{-6} \mathrm{M}\right): \mathrm{Cd}^{2+}\left(2.5 \times 10^{-6} \mathrm{M}\right) \quad 2$
B）拮㧧作用系
(6) $\mathrm{AM}\left(5.0 \times 10^{-5} \mathrm{M}\right): \mathrm{Mg}^{2+}\left(1.0 \times 10^{-4} \mathrm{M}\right) \quad 0.5$
(7) $\mathrm{S} \mathrm{M}\left(5.0 \times 10^{-7} \mathrm{M}\right): \mathrm{Mg}^{2+}\left(5.0 \times 10^{-5} \mathrm{M}\right) \quad 0.01$
(8) $\mathrm{Col}\left(4.0 \times 10^{-5} \mathrm{M}\right): \mathrm{Mg}^{2+}\left(5.0 \times 10^{-5} \mathrm{M}\right) \quad 0.8$
(9) $\mathrm{Col}\left(4.0 \times 10^{-5} \mathrm{M}\right): \mathrm{U}^{6+}\left(5.0 \times 10^{-6} \mathrm{M}\right) \quad 8^{\circ}$ 
表（7）協力作用における Col と $\mathbf{C d}^{2+}$ の嚄度比の関係

\begin{tabular}{|c|c|c|c|c|c|c|c|c|c|}
\hline $\mathrm{Cd}^{2} \mathrm{Col}(\mathrm{M})$ & $\begin{array}{l}\stackrel{0}{0} \\
\stackrel{x}{x} \\
\dot{0}\end{array}$ & $\begin{array}{l}\stackrel{0}{0} \\
\frac{1}{x} \\
0 \\
\dot{0}\end{array}$ & $\begin{array}{l}3 \\
\times \\
10 \\
0 \\
0\end{array}$ & $\begin{array}{l}= \\
x \\
0 \\
0 \\
-i\end{array}$ & 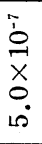 & $\begin{array}{l}x \\
x \\
10 \\
\text { in }\end{array}$ & $\begin{array}{l}= \\
x \\
0 \\
i \\
-i\end{array}$ & $\begin{array}{l}\stackrel{0}{0} \\
\stackrel{\vec{x}}{x} \\
0 \\
\dot{0}\end{array}$ & 0 \\
\hline $5.0 \times 10^{-4}$ & ..... & $\cdots$ & . & （沈 & & 澱） & $\cdots$ & $\cdots$ & $\cdots$ \\
\hline $2.5 \times 11$ & - & - & - & - & - & - & - & - & $H$ \\
\hline $1.0 \times \prime \prime$ & - & - & - & - & - & - & + & $H$ & $\mathrm{HH}$ \\
\hline $5.0 \times 10^{-5}$ & - & 一 & - & - & - & - & $H$ & $H$ & HH \\
\hline $2.5 \times \prime \prime$ & - & - & - & - & - & + & $H$ & $H$ & $\mathrm{HH}$ \\
\hline $1.0 \times 11$ & - & - & - & - & $H$ & $H$ & $H$ & $H$ & $\mathrm{HH}$ \\
\hline $5.0 \times 10^{-6}$ & - & - & + & $H$ & $H$ & H & H & $H$ & $\mathrm{HH}$ \\
\hline $2.5 \times 11$ & - & + & $H$ & $\mathrm{HH}$ & $\mathrm{HH}$ & $\mathrm{HH}$ & $\mathrm{HH}$ & $\mathrm{HH}$ & $\mathrm{HH}$ \\
\hline 0 & - & $H$ & $H$ & $H$ & $H$ & $\mathrm{HH}$ & $\mathrm{HH}$ & $\mathrm{HH}$ & $\mathrm{HH}$ \\
\hline
\end{tabular}

表（8）拮抗作用における $\mathbf{A M}$ と $\mathbf{M g}^{2+}$ の浱度比の関係

\begin{tabular}{|c|c|c|c|c|c|c|c|}
\hline $\begin{array}{r}\mathrm{AM} \\
(\mathrm{M}) \\
\mathrm{Mg}^{2+}(\mathrm{M}) \\
\end{array}$ & 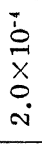 & $\begin{array}{l}= \\
x \\
0 \\
-1\end{array}$ & $\begin{array}{l}\stackrel{0}{0} \\
\stackrel{1}{x} \\
0 \\
0\end{array}$ & $\begin{array}{l}i \\
x \\
\text { in } \\
\text { in }\end{array}$ & $\begin{array}{l}\overline{1} \\
\times \\
0 \\
0\end{array}$ & $\begin{array}{l}\dot{0} \\
0 \\
\\
\times \\
0 \\
0\end{array}$ & 0 \\
\hline $1.0 \times 10^{-3}$ & - & $H$ & $\mathrm{HH}$ & $\mathrm{HH}$ & H & $\mathrm{HH}$ & $\mathrm{HH}$ \\
\hline $5.0 \times 10^{-4}$ & - & + & $\mathrm{HH}$ & $\mathrm{HH}$ & $\mathrm{HH}$ & $\mathrm{HH}$ & $\mathrm{HH}$ \\
\hline $2.5 \times 11$ & - & 一 & $\mathrm{HI}$ & $\mathrm{H}$ & $\mathrm{HH}$ & $\mathrm{HH}$ & $\mathrm{HH}$ \\
\hline $1.0 \times \prime \prime$ & - & - & $H$ & $\mathrm{HH}$ & $\mathrm{HH}$ & $\mathrm{HH}$ & $\mathrm{HH}$ \\
\hline $5.0 \times 10^{-5}$ & - & - & 一 & $H$ & $H$ & $\mathrm{HH}$ & $\mathrm{HH}$ \\
\hline 0 & - & - & - & $H$ & $H$ & $\mathrm{HH}$ & $\mathrm{HH}$ \\
\hline
\end{tabular}

表 (9) 拮抗作用における $\mathbf{S M} と \mathbf{M g}^{2+}$ の渪度比の関係

\begin{tabular}{|c|c|c|c|c|c|c|}
\hline 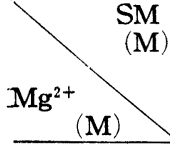 & $\begin{array}{c}\dot{0} \\
\stackrel{0}{0} \\
\times \\
0 \\
0 \\
10\end{array}$ & $\begin{array}{l}z \\
x \\
10 \\
0\end{array}$ & $\begin{array}{l}= \\
x \\
0 \\
-1\end{array}$ & 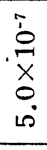 & $\begin{array}{l}z \\
x \\
10 \\
0\end{array}$ & 0 \\
\hline $1.0 \times 10^{-3}$ & - & $H$ & $H$ & $H$ & $H$ & $H$ \\
\hline $5.0 \times 10^{-4}$ & 一 & + & $H$ & $H$ & $H$ & $H$ \\
\hline $2.5 \times 11$ & - & - & $H$ & $H$ & $H$ & $H$ \\
\hline $1.0 \times 11$ & - & 一 & + & $H$ & $H$ & $H$ \\
\hline $5.0 \times 10^{-5}$ & - & - & - & $H$ & $H$ & $H$ \\
\hline $2.5 \times 11$ & - & - & - & + & $H$ & $H$ \\
\hline 0 & - & - & - & + & $H$ & $H$ \\
\hline
\end{tabular}

は両者の最小濃度比沈 0.5 -5の範囲にあり大体等モル 量附近で作用すると考えられる。一方, 拈祅作用系では SM-Mg 系の0.01の如く両者の比率が著しく相違する場 合が含まれていた。協力作用系と拮抗作用系との各最小 作用濃度を比較すると一般汇前者の方がや〉小さい。ま
(10) 拮抗作用における $\mathrm{Col} と \mathbf{M g}^{2+}$ ， の濃度比の関係

\begin{tabular}{|c|c|c|c|c|c|c|c|c|}
\hline $\begin{array}{c}\text { Col } \\
(\mathbf{M})\end{array}$ & $\begin{array}{l}\underset{i}{0} \\
\vec{x} \\
\underset{\forall}{0} \\
\dot{0}\end{array}$ & $\begin{array}{l}\Sigma \\
x \\
o v \\
n\end{array}$ & $\begin{array}{l}= \\
x \\
0 \\
-i\end{array}$ & $\begin{array}{l}\stackrel{0}{0} \\
\stackrel{0}{x} \\
0 \\
\infty \\
\infty\end{array}$ & $\begin{array}{l}= \\
x \\
0 \\
\dot{\nabla}\end{array}$ & $\begin{array}{l}x \\
x \\
0 \\
0 \\
0\end{array}$ & $\begin{array}{l}\Sigma \\
x \\
0 \\
-i\end{array}$ & 0 \\
\hline $1.0 \times 10^{-2}$ & $H$ & $H$ & $H$ & $H$ & $H$ & $H$ & $H$ & $H$ \\
\hline $5.0 \times 10^{-3}$ & + & $H$ & $H$ & $H$ & $H$ & $H$ & $H$ & $H$ \\
\hline $2.5 \times 11$ & + & $H$ & $H$ & $H$ & $H$ & $H$ & H & $H$ \\
\hline $1.0 \times \prime \prime$ & - & - & + & $H$ & $H$ & $H$ & $H$ & $H$ \\
\hline $5.0 \times 10^{-4}$ & - & - & - & - & $H$ & $H$ & $H$ & $H$ \\
\hline $2.5 \times \prime \prime$ & - & - & - & - & $H$ & $H$ & $H$ & $H$ \\
\hline $1.0 \times 11$ & - & - & - & - & $H$ & $H$ & $H$ & $H$ \\
\hline $5.0 \times 10^{-5}$ & - & - & - & - & + & $H$ & $H$ & $H$ \\
\hline $2.5 \times 11$ & - & - & - & - & - & + & $H$ & $H$ \\
\hline 0 & - & - & - & - & - & + & $H$ & $H$ \\
\hline
\end{tabular}

表（11）拮抗作用における Col と $\mathbf{U}^{6+}$ の濃度比の関係

\begin{tabular}{|c|c|c|c|c|c|c|c|c|}
\hline $\begin{array}{r}\text { Col } \\
(\mathrm{M})\end{array}$ & $\begin{array}{l}\dot{i} \\
\stackrel{\overrightarrow{1}}{x} \\
\underset{\forall}{0} \\
\dot{0}\end{array}$ & $\begin{array}{l}= \\
x \\
\text { ஸे } \\
\dot{n}\end{array}$ & $\begin{array}{l}= \\
x \\
0 \\
-1\end{array}$ & $\begin{array}{l}\stackrel{p}{0} \\
\stackrel{0}{1} \\
\times \\
0 \\
\infty\end{array}$ & $\begin{array}{l}= \\
x \\
0 \\
\dot{y}\end{array}$ & $\begin{array}{l}\mathbf{x} \\
x \\
0 \\
\text { o. }\end{array}$ & $\begin{array}{l}= \\
x \\
0 \\
-i\end{array}$ & 0 \\
\hline $5.0 \times 10^{-4}$ & ....... & $\cdots$ & $\cdots$ & & 澱 & $\cdots$ & $\ldots$ & $\cdots$ \\
\hline $2.5 \times 11$ & (沈) & $H$ & $H$ & $H$ & $H$ & $H$ & $H$ & $H$ \\
\hline $1.0 \times 11$ & $H$ & $H$ & $H$ & $H$ & $H$ & $H$ & $H$ & $H$ \\
\hline $5.0 \times 10^{-5}$ & - & - & + & $H$ & $H$ & $H$ & $H$ & $H$ \\
\hline $2.5 \times 11$ & - & - & + & + & $H$ & $H$ & $H$ & $H$ \\
\hline $1.0 \times 11$ & - & - & - & - & + & $H$ & $H$ & $H$ \\
\hline $5.0 \times 10^{-6}$ & - & - & - & - & + & $H$ & $H$ & $H$ \\
\hline $2.5 \times 11$ & - & - & - & - & - & $H$ & $H$ & $H$ \\
\hline 0 & - & - & - & - & - & $H$ & $H$ & $H$ \\
\hline
\end{tabular}

た各系の金属イオンにつき，抗生物質と共存した場合の 最小作用濃度を夫ふの単独作用濃度と比較すると, AMCd 系では $1 / 50, T M-B a$ 系では $1 / 250$ 以下, TC-Cr 系て は 1/40 以下, SM-Cd 系では 1/250 以下, Col-Cd系では $1 / 100$ であつた。但し拮抗作用系 $(\mathrm{Mg}$ 及び U) では著し い単独作用濃度は認められなかつた。さて各系に招ける 金属イオンの影響は, 先きに傾斜平板法の成績から推定 された通り原則として金属イオン濃度の増減と平行関係 を示して。しかし，TM-Ba 系の協力作用に関しての及 虫, $\mathrm{Ba}$ 濃度 $10^{-3} \mathrm{M}$ の場合淮力作用が最大であり $\mathrm{Ba}$ 濃度が $2.5 \times 10^{-3} \mathrm{M}$ 以上飞増加すると却つて非協力的化 なる事実が認められた。また各系の協力又は拮抗作用化 関し，金属イオンの影響が濃度の変化につれ比較的階段 的増減する場合 (AM-Cd 系, TC-Cr 系, Col-Cd 系, 
AM-Mg 系及び SM-Mg 系) と或濃度で比較的飛躍的に 增減する場合 (TM-Ba 系, SM-Cd 系, Col-Mg 系及び Col-U 系) とが区別された。

\section{考 察}

今回の諸実験で得られた各成績について, まとめて考 察するといくつかの注目すべき問題が挙げられる。

1. 抗生物質の種類による差異(錯塩形成の可能性): 使用抗生䓄質 9 種中で各種金属イオンの影響を最も敏感 に受けたのは, Tetracyclin 系物質(AM, TM 及び TC) と $\mathrm{Col}$ であり, S M と It は中等度, $\mathrm{Pc}, \mathrm{CM}$ 及び $\mathrm{OM}$ の三者は著しい影響を受けなかつた。との㥆な成績か ら, 各抗生物質についてその化学構造や抗菌作用点の異 同が或程度推定出来た。即ち, 先ず Tetracyclin 系物質 3 種は各種金属イオンの影響に関してもやはり互に殆ど 同様の傾向を示した。しかし個々の金属イオンの影響程 度には 3 種の間にも可成り差異があり,一般に $\mathrm{TC}>\mathrm{TM}$ $>\mathrm{AM}$ の順序で安定した成績が得られた。之は 3 者の化 学構造や抗菌作用点の差異の他倍地中の安定度とも関 連するものであろう。さて既に第 1 報”で報告した様に， $\mathrm{AM}$ は多数の金属 $\left(\mathrm{Al}^{3+}, \mathrm{Ca}^{2+}, \mathrm{Fe}^{2+}, \mathrm{Mg}^{2+}, \mathrm{Th}^{4+}, \mathrm{U}^{6+}\right.$ 及び $\mathrm{Zr}^{4+}$ 等) と錯塩形成を行うと推定され, 石館・坂 口4) の研究によれば更に $\mathrm{Bi}^{3+}, \mathrm{Co}^{2+}, \mathrm{Cu}^{2+}, \mathrm{Hg}^{2+}$ 等々 の錯塩形成も認吼た。故に, Tetracyclin 系物質々 各種金属イオンの協力乃至拮抗作用中に汕両者の 錯塩 (金属キレート化合物) 椡成汇由来するものが相当数含 まれていると考えられる。その裏づけの意味で注目すべ きは TM-Ba 系の協力作用に打ける Ba 濃度已抗菌性 変化の関係であろう。本系では $\mathrm{Ba}$ 濃度が $10^{-3} \mathrm{M}$ の場合 に抗菌性が最大であり，之が $2.5 \times 10^{-3} \mathrm{M}$ 汇高まると協 力效果隐激汇減少し更に $5.0 \times 10^{-3} \mathrm{M}$ 亿増加すると逆 に著しい拮抗作用が認めら㣗た。との際, 高濃度の $\mathrm{Ba}$ イオンによるTMの分解は否定されたから，との様な抗 菌性变化滕式は単に TM $\mathrm{T}$ と $\mathrm{Ba}$ の各単独作用の相加では 説明出来ない。従つてTM 新しい第三の抗菌性物質が生ずるとと即ち両者の結合に よる錯塩形成が強く推定される。Albert 等 ${ }^{11}$ は $S t$. aureus や Str. pyogenes に対する 8-Oxychinolin-Fe 錯 塩の抗菌性につき，両者が $1: 1 て ゙$ 結合する場合は強い 抗菌力を発揮するが，薬剤濃度が増して $2: 1$ で結合す る様になると全く無効になる事実を報告している。上述 の TM-Ba 系の錯塩形成と抗菌性変化汇関しても之と添 ぼ同样の関係が存在するのではあるまいか。しかし，水 溶液中に打ける錯塩形成の可能性の有無乃至強弱 と実際
に打ける抗菌性変化の有無乃至強弱とは必ずしも皆一致 平行するわけではない。とれは勿論, 生ずる錯塩の抗菌 性が原物質のそれから著しく変化するか否かの問題であ るが, 同時化考元ら机るととは後述する如く培地中の諸 成分特に元来含有されている各種金属イオンの干涉作用 であろう。な扔他方, 各系の金属イオンについて前述の 如く，抗生物頭と共存した場合の最小作用濃度が夫々の 単独作用濃度に比べて数十乃至数百分の一の微量である 点や単独作用濃度为比較的低い $\mathrm{Cd}$ の場合も抗生物質の 種類により全く影響が認められない点, 更に単独作用濃 度が $\mathrm{Cd}$ よりも高い $\mathrm{Ba}$ や Cr の影響濃度が逆に Cd より低い点等の諸成績加も, 各抗菌作用点の变化や細 菌住対す金属つ直接作用以外の機作の存在が 推定され る。結局, 抗生物質の抗菌性化及ぼす金属イオンの影響 の有無乃至程度は全く両者の組合世の種類如何に依存す るわけである。従つて, Tetracyclin 系物質のみならず $\mathrm{Col}$ ? $\mathrm{S} \mathrm{M}$ 等に関しても夫及各種金属錯塩形成の可能性 が強いだろう。

2. 使用菌株の種類による差異 : 同一の抗生初質一金 属系の成績注いても， E. coli を使用した場合と St. aureus を使用した場合とで, 又.同一菌種でも薬剤感受性 菌と同耐性菌とのぞちらを使用するかで可成りの差異が 認められた。例えば同じ Cd の影響でも, Tetracyclin 系㸮質や Col では E. coli に対して著しくS Mでは逆に St. aureus に対して著しかつた。坛た搪散法の成績に 执いて，E. col の薬剂感受性菌と $\mathrm{S} \mathrm{M}$ 耐性菌や T M 耐 性菌等の相互間で或程度の差:異が認められた。上野の報

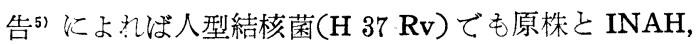
TB-1, SM 等の各耐性菌との間で金属イオンの影響に 相当の差:異が認められている。赤沢6) は大腸菌やブドウ 球菌等老緩衝液で洗桬し, 洗沙菌体の呼吸低下が菌体金 イオンの損失に原因すると之，その呼吸低下の程度や金 属イオン添加による呼吸賦活効果が菌種により著しく異 るととを報告した。

以上の様な諸成績から，菌種の相違や薬剤感受性の変 化により細菌のメタボリズム即ち䣼素系汇差:異があり， 従つて之に作用する抗生物質一金属系の影響も必然的に 異ると考えられる。しかし，Gram 陽性菌と Gram 陰 性菌との間に金属イオン感受性の点で共通の差異が存在 するかぞうか，更に細菌の抗生物質耐性の獲得と金属イ オン感受性の変化との間に特種な相互関係があるか否か 等の諸問題は更汇今後の検討行待ちたい。

3. 其他の実験条件による差異 : 第 1 報 ${ }^{11}$ 及び第 2 報2)の成績と今回の成績とを比較すると同一の抗生初質 
一金属系についても明らかに相当の差異があり，とれは 多く抗生物質や菌株以外の各種実験条件の差異に由来す るものと考えられた。例学汸同じ拡散法でもCup 法の 様に抗生物質と金属イオンを蒸溜水中で接触させた前回 々, 今回の傾斜平板法の如く両者を寒天培地中で拡散京 介して接触させた場合とは当然条件が異る。また同じ液 体培地の稀釈法でも, 前回の様冷精製合成培地々今回の ふつうブイヨン培地ではやはり条件が異る。添加金属イ オンの影響を検討する場合, 最も問題になるものは之之 反応する培地中に含まれる各種金属イオンの影響である 弓。従来の諸報告 ${ }^{7,8)}$ によればペプトン, 肉エキス, 寒 天, 蒸溜水等の中には既に多くの金属 $(\mathrm{Al}, \mathrm{Cu}, \mathrm{Fe}, \mathrm{Mg}$, $\mathrm{Mo}, \mathrm{Mn}, \mathrm{Ni}, \mathrm{Sn}$ 及び $\mathrm{Zn}$ 等) が或程度 (約 $10^{-7}$ 一 $10^{-5} \mathrm{M}$ 位) 含有されている。従つて, 培地中で観察され た添加金属イオンの影響は一般に各種培地諸成分特に培 地金属イオンとの競争の結果出現したものと考うべきで あろう。

\section{結 論}

St. aureus, E. coli, Vibrio cholerae 等を用いて, 抗 生物質 9 種 (Aureomycin, Terramycin, Tetracyclin, Penicillin, Dihydrostreptomycin, Ilotycin, Chloromycetin, Oleandomycin, Colimycin) の各抗菌力に玄活 す各種金属イオン 20 種 $(\mathrm{Ag}, \mathrm{Al}, \mathrm{Ba}, \mathrm{Ca}, \mathrm{Cd}, \mathrm{Co}, \mathrm{Cr}$, $\mathrm{Cu}, \mathrm{Fe}^{2+}, \mathrm{Fe}^{3+}, \mathrm{Hg}, \mathrm{Li}, \mathrm{Mg}, \mathrm{Mn} \mathrm{Ni}, \mathrm{Pb}, \mathrm{Th}, \mathrm{U}, \mathrm{Zn}$, $\mathrm{Zr}$ ) の影響を夫く寒天拡散法 (二重傾斜平板法) とブイ ヨン稀釈法により比較検討した。その結果,

1）傾斜平板法により，抗生物質一金属系 46 種 (協力 作用17種, 拮抗作用29種）に抬いて夫々抗菌性の変化を 認めた。特に, Tetracyclin 系三物質, Ilotycin 及び Colimycin に対する Cd の各協力作用, Tetracyclin 系三㸮質に対する $\mathrm{Fe}^{2+}$ と $\mathrm{Mg}$ の各拮抗作用, Dihydrostreptomycin とIlotycin に対する $\mathrm{Mg}$ の各拮抗作用 (但し特に St. aureus 使用の場合) 等が著しかつた。

2）ブイヨン稀釈法により，抗生物質一金属系 67 種 (協力作用 27 種, 拮抗作用 40 種) に捛いて夫久抗菌性の
変化を認めた。特に, Tetracyclin 系三物質に対する, $\mathrm{Ba}, \mathrm{Cd}$ 及び $\mathrm{Cr}$ の各協力作用と $\mathrm{Mg}$ の拮抗作用, Dihydrostreptomycin (特に St. aureus 使用の場合) に対 する Cd の協力作用之 Mg の拮抗作用, Colimycin に 対する Cd の協力作用 (特に E. coil 使用の場合) と $\mathrm{Mg} や \mathrm{U}$ の各拮抗作用 (共に St aureus 使用の場合) 等が顕著であつた。

3）特に顥著な協力又は拮抗作用を示した上記の抗生 物質一金属系 9 種につき, 夫《両者の濃度比と抗菌性変 化亡の関係を検討した。

4）抗生㸮質の抗菌力に及ぼす各種金属イオンの影響: が, 抗生物質の種類, 使用菌株の差異 (菌種又は抗生物 質感受性の差異等), 更に其他の実験条件により著しく 変化する事実を知り各機作に関して夫々考察を加えた。

本研究の実施に当り終始御指導を賜つた秋葉朝一郎教 授に深謝致します。まを有益なる御助言を賜つれ千葉大 学薬学部坂口武一教授, 東大薬学部田村善三助教授, 結 核子防会結核研究所上野高正部長, 田辺製菜鶴岡正夫博: 士の各御好意飞深謝致します。

\section{文 献}

1）氏家：日本細菌学雑誌，10(9), 771, 1955.

2）氏家：日本細菌学雑誌，10(10), 823，1955.

3) Weinberg, E. D. : Science, 125 (263), 196, 1957.

4) Ishidate, M. \& Sakaguchi, T. : Pharm. Bull. (Japan), 3(2), 147, 1955.

5) 上野: 薬学雑誌, $76(7), 825,1956$.

6) 赤沢：岡山医学会雑誌, $66(5), 1009,1954$.

7) 久保, 金久保: 薬唷部長年報 (日本薬剂師協会雑誌 薬削学特集号) $15,2: 19,1955$.

8) Albert, A.: Selective Toxicity with Special Reference to Chemotherapy, Methuen \& Co., London, 1951.

9) 坂口, 真下: 日本化学療法学会雑誌, 4(1), 41, 1956.

10) Kämmerer, H. et al. : Klin. Wochenschr., 30 , 1083, 1952.

11) Albert, A., Gibson, M. I. \& Rubbo, S. D. : Brit. J. Exptl. Pathol., 34, 119, 1953. 